\title{
Living in the Industrial City: \\ Housing Quality, Land Ownership and the Archaeological Evidence from Industrial Manchester, 1740-1850
}

Accepted Author's version published in the International Journal for Historical Archaeology, Volume 15, Issue 4 (September 2011), pp. 594-606

DOI 10.1007/s10761-011-0159-5

\begin{abstract}
This paper looks at the recent archaeological evidence for industrial housing in Manchester, United Kingdom. The paper argues that a fragmented land-holding pattern developed in a number of city-centre areas during the second half of the eighteenth century. That this land-holding pattern made these areas susceptible to overcrowding through the domestic redevelopment of back yard plots and the conversion of older housing to tenements. This redevelopment was at its most acute during the peak decades of population growth in the city, 1800-40, and this led to the slum conditions of poverty, disease and overcrowding recorded in contemporary accounts from the mid-nineteenth century.
\end{abstract}

Keywords: Back-to-backs; Cellar dwellings; Land-holding; Manchester; Workshop dwellings.

Dr Michael Nevell, MIFA, FSA

Head of Archaeology

Centre for Applied Archaeology

School of the Built Environment, University of Salford

Joule House, Crescent

Manchester M1 4NW UK

Email: m.d.nevell@salford.ac.uk

\section{Introduction}

Industrial housing (workshop dwellings, blind-backs, back-to-backs and throughhouses) was a necessary counterpart to the urban, steam-powered, factory. Factory owners' needed to be able to guarantee a regular supply of labour, in return for standardised wages and hours. A new landless tenantry, accommodated in purposebuilt urban houses, emerged to fulfill this need in the industrializing cities of eighteenth and nineteenth century Britain. In the last decade historical archaeologists and industrial archaeologists from Britain have been involved in recording large numbers of such housing either through standing building surveys or through excavations. Notable areas of activity have included Birmingham, Glasgow, London, Sheffield, and York (Belford 2006; Connelly et al 2008; Jeffries et al 2009, pp. 323-8; Morton 2009; Symonds 2005, pp. 56-62). In interrogating and organising this growing body of data researchers have to be aware of the dangers in maintaining a 
separation between the archaeological and architectural evidence, and in assuming that nineteenth- and early twentieth-century views of 'slum' areas were accurate and applied to earlier periods as well (Belford 2004, pp. 167-9). Archaeology is now the only way of revealing the extent and quality of this housing in most of these industrial cities and the recent economic boom and consequent building activity has provided the opportunity to study, archaeologically, industrial housing in one of the world's 'shock cities': Manchester.

Manchester was, and perhaps still is, a controversial city. It was described around 1540 by the antiquarian John Leyland in almost idyllic terms as the 'the fairest, best buildid, quickest and populus tounne of al Lancastreshire' (Bradshaw 1987, 8-10). Visitors in the late seventeenth and eighteenth centuries commented upon the town's lack of government, its domestic-based industry and the great increase in its streets and buildings. Those viewing the city in the nineteenth century were astounded or more often horrified by the city's industrial face, the hundreds of cotton factories and warehouses, the narrow alleyways, courts and over-crowded houses, most of which were packed into the present twenty-first-century city centre. Frederich Engels' description of Manchester is the best known and most debated of the many visitors' sketches of the city. Writing in 1842-43, but published later in his book The Condition of the Working Class in England, his descriptions of housing and living conditions within the city have become infamous. Engels (Engels 2005, p. 100) concluded that the '350,000 working people of Manchester and its environs live, almost all of them, in wretched, damp, filthy cottages, that the streets which surround them are usually in the most miserable and filthy condition, laid out without the slightest reference to ventilation, with reference solely to the profit secured by the contractor' His comments came after more than 60 years of rapid urban and industrial expansion and at the end of a 20 year period when Manchester doubled its population size, but not its physical area (Fig 1). He was thus writing at the most acute period in Manchester's housing provision and at the peak of the overcrowding of this new industrial city.

The rapid factory-based industrialisation of the late eighteenth and early nineteenth century coincided with a phenomenal rise in population in many industrializing cities in Britain, from Birmingham and Glasgow to London and Sheffield. Even established county towns such as York saw significant population increase and industrialization. Manchester nearly doubled its size between 1801 and 1821 from 75,281 to 126,066 people, and then more than doubled it by 1851, when there were 303,382 people within the new borough (Hartwell 2001, p. 17). This new population required huge amounts of housing and between 1773 and 1821 the number of dwellings in the city rose from 3446 to 17,257 (Kidd 2002, p. 38), and by 1851 had reached nearly 50,000 houses.

Until the late twentieth century few physical remains of workers' housing from this period were recognised within the city. Survey work in the 1980s and 1990s rediscovered dozens of surviving eighteenth-century houses and between 2001 and 200914 excavations revealed the remains of housing from the eighteenth and nineteenth centuries in the very heart of industrial Manchester (Nevell 2008). For the first time archaeology is able to augment the contemporary accounts of social commentators such as Aikin, Engels and Kay with physical evidence, some of which shows such reports to be exaggerated, whilst other finds demonstrate that these reports underestimated the worse aspects of contemporary industrial Housing (Aikin 1795, pp. 192-5; Kidd \& Wyke 2010).

One of several themes to emerge from this archaeological evidence was the issue of housing quality and land ownership. There is a marked decline in the quality of 
workers' housing between the late eighteenth century and those of the 1820 s and 1830s, the latter being particularly notable for their poor build-quality and cramped conditions. This coincided with the rise of small-scale land-owners and renters who speculated in building housing on tiny plots. This paper explores how far land ownership was a significant factor in the emergence of slum housing - that is overcrowded and insanitary domestic housing - along the way discussing models for the emergence of slum housing in the world's first industrial city.

\section{Eighteenth Century Workers’ Housing}

The evidence for industrial housing within the twenty-first century city centre of Manchester, which covers the area of the eighteenth and early nineteenth century industrial city, falls into two categories: standing remains and below-ground archaeology. Research undertaken during the 1980s and 1990s revealed a large number of surviving eighteenth-century vernacular workshops, or as they are known locally workshop dwellings, within this area. Such dwellings were characteristic of the protoindustrialisation process which relied heavily on hand-manufacturing processes particularly in the textile sector (Palmer 2004, p. 3-7). The workshops within the city were typically three-storeys high with a cellar and were usually one room or one bay deep. The upper, or attic, storey contained a workshop lit by distinctive long multi-light windows and the cellar was often also used as a workshop. Since handloom weavers' earned higher pay than cotton spinners the speculative building of such properties in an established textile manufacturing centre such as Manchester was an attractive proposition for an eighteenth-century property speculator (Taylor and Holder 2008, p. 12).

The largest concentration of weavers' cottages in eighteenth century Manchester lay in the Northern Quarter, then known as the St Paul's district (see Fig 1). This area was one of 14 special constable districts that had developed by 1800 as the town more than trebled in size during the eighteenth century. It lay to the north-east of the medieval core of Manchester (Taylor and Holder 2008, p. 11) and was defined by the following streets: on the east by Lever Street, on the north by Great Ancoats Street and Swan Street, on the west by Shude Hill, Nicholas Croft and High Street, and on the south by Market Street and Piccadilly. Map evidence indicates that the street pattern of this district has remained largely intact since the eighteenth century. The houses and commercial premises of this district were built on land originally owned by the Lever family which was progressively sold during the eighteenth century to speculative house builders and textile merchants. Cartographic evidence from the eighteenth century shows that this area went from open fields to being almost completely built upon by housing in less than 60 years.

An analysis of the 1800 directory for Manchester indicates that the character of the St Paul's district was that of a mixed working-class residential, commercial and manufacturing area (Nevell 2003, pp. 37-8). Of the 114 people listed as resident in the St Paul's district, the largest single grouping was textile workers and manufacturers. The weavers' cottages of the St Paul's District in the Northern Quarter were mostly built between c. 1740 and 1800 either in pairs or runs of three, four, or five terraces. Of the many hundreds that once existed only 50 examples survived in this area by 2003 (Nevell 2003, p. 36). Six sets of these vernacular workshops have been studied in detail within a small urban block formed by Turner Street, Kelvin Street (formerly Milk Street), Back Turner Street and Brick Street (Fig 2). This block of land appears to have been divided into plots that were sold during the 1740 s and 1750 s by a 
merchant called Josiah Nicholls, who presumably had bought the land from the Lever family, to 17 individuals (Nevell 2005, 189-90). Green's map of 1794 indicates that virtually the whole of this block was built upon by 1794. The three Manchester directories published between 1772 and 1800 indicate that these streets contained a variety of occupations and different uses. Turner Street was dominated by the houses of manufacturers who had their business elsewhere, whilst the properties on Kelvin Street and Back Turner Street were occupied by craftsmen or tradesmen who lived and worked in the same buildings. Occupations mentioned in the trade directories from this period included timber, flour and tea dealers and sellers, as well as joinery, shoemaking, and textiles (Nevell 2003).

The historical background of a set of six vernacular workshop dwellings along Back Turner Street (nos. 36-38 Back Turner Street and nos. 1-5 Kelvin Street) dating from 1755 to 1800 was studied by the Manchester Early Dwellings Research Group in the 1980s (Roberts 1993, pp. 15-7). This study showed that they were all built on land which a slater, Peter Hall, had bought from the Lever family. Peter Hall was one of 17 speculative developers who acquired land in this area during the mid-eighteenth century (Nevell 2005, pp. 195-7). Of these six buildings, Nos. 1-5 Kelvin Street was the subject of a detailed archaeological survey in 1997 (Walker \& McNeil 1997; Nevell 2003). These three properties were built by Richard and Mary Manchester, fustian manufacturers, in 1772-73 and their layout shows they were built as a single working unit (Taylor and Holder 2008, pp. 15-17), with the top-floor workshops all linked. Internally, the ground and first floors of each property acted as the domestic areas, each floor being heated and perhaps divided by a wooden screen, and provided a total living area of $50 \mathrm{~m}^{2}$. Below was a cellar accessed only from the individual property, but each third-floor attic room was connected to the others, providing three linked workspaces with a taking-in door at the rear of the northern-most attic room. On the ground floor, a covered passageway between the southern and middle properties led to the rear enclosed courtyard and the area below the rear taking-in door. The scale and floor area of these workshops were comparable to the rural vernacular workshops being built around Manchester at this time and a similar level of social control in terms of how the working space was accessed and arranged.

The redevelopment of the city centre since 1996 has given the opportunity to excavate several examples of this type of early working-class housing, all pre-dating 1794 (Fig 3; Nevell 2008). The fragmentary basement remains of a set of vernacular workshops were excavated on the southern side of Copperas Street in 2004. In 2005 a single vernacular workshop was excavated on the southern side of Angel Street in Angel Meadow. A well preserved example of two vernacular workshop basements was excavated in 2005 on Southern Street in Castlefield. Each property was divided into a front cellar room measuring $5 \times 3.7 \mathrm{~m}$ and a rear, cellar room measuring $5 \mathrm{x}$ $2.7 \mathrm{~m}$. Where the original floor levels survived these were formed by a series of unbounded red handmade bricks laid on their sides. There was a fireplace or range in each front room whilst sometimes the rear cellar room had a smaller fireplace. The extremely limited finds material excavated from these sites included unglazed earthenwares, dark-glazed earthenwares, stoneware, transfer-printed wares from plates and pancheons (dishes) of the late eighteenth and early nineteenth centuries, suggesting that these basements had always been used as storage or domestic areas.

The weavers' cottage was thus a common form of working-class dwelling across Manchester by the end of the century. Such buildings were built by dozens of smallscale property speculators for the booming hand-loom weaving and hand-spinning cotton manufacturing industry in Manchester. They all followed the same broad 
pattern, being three storeys high with a cellar and an attic loomshop, and the domestic and working spaces evenly divided at around c. $60 \mathrm{~m}^{2}$ each. The combination of work and domestic spaces mirrored the textile vernacular workshops of the surrounding countryside (Palmer 2004, pp. 9-11) and in terms of floor area the living space was not noticeably smaller than farm labourers' and industrial labourers' housing of this period (Casella and Croucher 2010, pp. 98-100; Gwyn 2006, pp. 182-3; Nevell and Walker 1998, p. 78). Whilst a twenty-first century perspective might call these typical 'slum' dwellings because of their small-scale and a lack of sanitary facilities such as internal running water, the small amount of personal space and the shared external privies were all features of urban, domestic, working-class dwellings and were not remarkable to contemporary writers. Such properties were not, therefore, by contemporary standards 'slum' dwellings, but the fragmented nature of land-holding and the decline in the need for workshop dwellings meant that they would become one of the typical 'slum' dwellings types of the mid-nineteenth century.

\section{Early Nineteenth Century ‘Slum’ Housing}

Whilst such vernacular workshop dwellings represented on the whole good quality, single-family, artisan housing, by the end of the eighteenth century the rapid industrialisation of Manchester had begun to lead to a decline in housing standards and a sharp rise in population densities. These conditions would culminate in the overcrowded and insanitary living spaces recorded by Engels, Kay, Reach and other social commentators during the 1830s and 1840s. John Aikin (1795, p. 193) was probably the first to detail these problems, noting in 1795 that 'in some parts of the town, cellars are so damp as to be unfit for Habitations; ... I have known several industrious families lost to the community, by a short residence in damp cellars'. When the poet and historian Robert Southey visited Manchester in 1808 he was less than impressed with both the way the mills were worked and with the housing conditions of the mill hands: 'The dwellings of the labouring manufacturers are in narrow street and lanes, blocked up from light and air ... crowded together because every inch of land is of such value, that room for light and air cannot be afforded them', (Bradshaw 1987, 24).

A useful model of the way in which overcrowded, slum, housing developed during this period is represented by the upstanding remains of 69-77 Lever Street in the Northern Quarter (Fig. 4). These began as a speculative development of five-, fourstorey, workshop-dwellings built progressively over a decade by a plasterer, William Bradley (Taylor and Holder 2008, p. 24). The first phase spanned the period 1780-8 when a row of five houses was built. These had attic-floor workshops but the basements, ground and first floors appear to have been divided for tenement housing in all but one case. Each house had its own rear yard with an outside privy. The second phase saw two-storeyed extensions, lit separately, built into the rear yard areas by around 1790 and a third phase by 1794 saw one-up-one-down cottages added to the rear of these in turn, facing Bradley Street. Later in the early nineteenth century, by 1831 a five bay, three-storey, warehouse was built across two back yards. Access to the phase two and phase three housing was only from the Bradley Street side of the properties (Taylor and Holder 2008, p. 25). These properties encapsulate many of the features of later slum housing; small domestic unit size, poor lighting, restricted access through narrow alleyways and a lack of sanitation.

The development of the row of three weavers' cottage built by $\mathrm{Mr}$ and Mrs Manchester in 1772 is not as spectacular, archaeologically, but nevertheless provides 
another pattern for the emergence of slum dwellings from the older mid-eighteenth century housing stock. As hand-spinning and then hand-weaving declined the attic and cellar, as well as the existing ground and first floor living space, were rented as separate units. This was marked archaeologically by the blocking of the doorways linking the attic weaving spaces, the blocking of the rear taking-in door and the division of each floor into two rooms. Thus, a mid-eighteenth century property for one family was turned into a tenement for four or more families, with no extra provision of privies in the rear yard area.

These surviving examples can now be amplified by more than a dozen recent excavations of nineteenth century housing around Manchester and Salford. The variety of sizes and plan-forms seen on these excavations reflects both the fragmented land-holding pattern that had developed by about 1800 and the pressure of rising population densities.

Two characteristics emerged from these excavations - the lack of late eighteenthand nineteenth-century finds and the shallow foundations, often only two and three bricks deep. The excavations in 2001 off Liverpool Road revealed properties erected in the 1820s, the period of fastest growth in the city's population. These two-roomed houses had shallow brick foundations just three bricks deep and no outside privies (Connelly 2002). Excavations in 2011 revealed similarly shallow foundations and no privies from eight back-to-backs built earlier in the period 1794-1807 (Fig 5). At Greengate in Salford, on the western side of Manchester city centre, the remains of four blind-backs built in the 1820s were recovered (Noble \& Arrowsmith 2005). These were one-up-one-down houses and represented the lowest form of housing in the city. The only known examples left standing are those in Bradley Street from c. 1790-4 (see above). The Greengate examples had room sizes of less than 3.5m square with foundations of one brick depth, and whilst each ground floor room had a fireplace, there were no signs of any floor covering nor of a staircase and it is likely that the upper storey was accessed via a ladder. In contrast, the remains of Syer's court off Minshull Street at Piccadilly excavated in 2004 revealed the deeply stratified and well preserved remains of a set of seven back-to-back houses dating from the period 1831-36 (Miller, Wild \& Gregory 2010, pp 26-9). These had heated halfcellars that in places still stood to a height of $1.4 \mathrm{~m}$, with steps into the rooms, but with partition walls one-brick-thick and flagged floors on which some of the brick walls rested.

The excavations of two adjoining blocks of housing on the corner of Angel Street and Blakeley Street in 2009 provided the archaeological evidence for the development of backyard and court housing to complement the upstanding example of 69-77 Lever Street. Here parts of more than 30 individual properties were excavated. Housing development began after 1770 with the construction of weavers' cottages fronting Angel Street and Blakeley Street. By 1794 backyard building had already begun behind the Blakeley Street properties and by 1850 a new road had been put in to access the housing to the rear of the Blakely Street properties. By this date a court area had developed in the angle between the corner housing at the Blakeley Street and Angel Street junction. There was some evidence to show that the late eighteenth century weavers' cottages had been divided into tenements. This came in the form of the conversions of cellars into individual dwelling units. The archaeological evidence showed how the paved rear yards along Blakeley had one-unit housing built over the yards, re-using the flagged yard coverings. Further north the court housing of back-toback and single unit houses was accessed by a network of narrow alleyways or ginnells from Blakeley Street. 
It is tempting to view these intensively occupied pieces of urban landscape, with their increasingly restricted access, small communal areas and tiny (to us) domestic spaces, from the perspective of the mid-nineteenth and early twentieth-century social commentators, but that would be to overlook the contemporary social meanings of these sites (Belford 2004, pp. 175-7). Patterns of land ownership and land-holding clearly had a significant impact on the framework and growth of these urban landscapes, but they were then occupied and changed by successive tenants who were more concerned with the everyday problems of domestic and work life. What to some were 'slums' to others were vibrant communities and the archaeological evidence is likely to reflect this dichotomy. We might call this the archaeology of the household, although such a discussion in a Manchester context is beyond the scope of the present article (Jeffries et al 2009, 332-40).

\section{Conclusion}

The archaeological recording of surviving housing and the excavation of below ground domestic remains from Manchester between 1740 and 1850 is not exceptional, examples of similar work can be found in Glasgow, London and Sheffield for instance, but the range and density of housing recovered provide great potential in the research of the impact of immigration, sanitation, and gender on the identity of such new industrial cities. In the case of Manchester the specific role of patterns of landholding had a particular influence on the development of 'slum' housing within the city. Thus, it is possible to identify three main phases in the development of workers' houses within Manchester during this period.

Firstly, the initial sale of large estates such as the Lever family's led to the building of speculative weavers' cottages across the city but especially in the Northern Quarter district. The fragmented land-holding of the late eighteenth century was reflected in the building breaks of properties, showing that building projects encompassing one, two and three houses were common and rows of more than six uncommon in this period.

Secondly, there was a rapid growth in house numbers, form and type as the city's population and industrialisation accelerated in the first three decades of the nineteenth century. New workers' housing areas were developed in Castlefield, the eastern side of the Northern Quarter and Ancoats. This housing was for the new landless urban tenantry, many of whom were immigrants who had come to work in the newly built steam-powered cotton mills of the city. They were characterised by back-to-backs, cellar dwellings and courtyard developments accessed by ginnells that twisted and turned through earlier property boundaries and buildings. Nos. 69-77 Lever Street provides one model of how court housing developed during this period. Here, the phase two and three housing was built upon the backyards of earlier properties and access was only from the rear side of the primary properties. In effect, each backyard became its own small court housing area. The archaeological excavations of housing between Angel Street and Blakeley Street shows how complex and enduring such backyard and court housing could be. What this urban backyard development reflects is the packing of more and more housing units onto the tiny properties held by small landholders, whether tenants or land-owners.

Thirdly, as hand-spinning and then hand-loom weaving declined the older vernacular workshops of the eighteenth century became available for multipleoccupancy, as at nos. 1-5 Kelvin Street, leading to some of the worst examples of 
overcrowding in the city, as in the Angel Meadow area and Northern Quarter for instance.

Thus, the fragmented landholding pattern of eighteenth century Manchester appears to have enabled and encouraged the conversion of existing housing into tenements, and backyards into courts during the early nineteenth century as ways of maximising the rental return from small-scale properties. The housing types that emerged in these areas appear to have set the pattern for the cellar dwellings, courts and back-to-back houses that were built on green-field sites in the Ancoats and Castlefield areas of the city during the 1820s, 1830s and 1840s, a period of unplanned and unrestricted growth typical of many contemporary industrializing cities (Symonds 2005, 63-4). One can argue that the valuable commodity here was not the house nor the land but the tenant and that this is recorded in the archaeology of the properties themselves.

\section{Acknowledgements}

Much of the fieldwork mentioned in this article was undertaken by staff from the University of Manchester Archaeology Unit, in effect the city's own field unit which functioned from 1994 to 2009. The resultant 'grey literature' reports are now held by the Greater Manchester Archaeology Unit as County Archaeological Curator. Ian Miller of Oxford Archaeology North kindly supplied the photograph of the Angel Street/Blakeley Street excavations, English Heritage gave permission to reproduce the reconstruction of 66-77 Lever Street, and Terry Wyke of Manchester Metropolitan University gave permission to adapt the police districts map. My thanks go to every member of UMAU in recovering this important material. My thanks also go to Paul Belford, Marilyn Palmer, Norman Redhead, Jim Symonds and John Walker with whom I have debated the thrust of this 'slum' argument for many years.

\section{References}

Aikin, J., 1795, A Description of the Country Thirty to Forty Miles round Manchester. London.

Belford P, 2004, 'Urban Industrial Landscapes: Problems of Perception and Protection', in Barker D \& Cranstone D, (eds), The Archaeology of Industrialization. Papers given at the Archaeology of Industrialization Conference, October 1999. The Society for Post-Medieval Archaeology, Leeds.

Belford P, 2006, 'The World of the Workshop: Archaeologies of Urban Industrialisation' in Green A \& Leech R, (eds), Cities in the World, 1500-2000. Papers given at the Conference of the Society for Post-Medieval Archaeology, April 2002. Society for Post-Medieval Archaeology, Monograph 3, 133-49.

Bradshaw L D, 1987, Visitors to Manchester. A Selection of British and Foreign Visitors' Descriptions of Manchester from c. 1538-1865. Neil Richardson Publications.

Casella E C \& Croucher, S K, 2010, The Alderley Sandhills Project. An Archaeology of community life in (post) Industrial England. Manchester University Press.

Connelly P A, 2002, 73/83 Liverpool Road, Manchester. An Archaeological Excavation within the Roman Vicus. Excavation Report. University of Manchester Archaeology Unit, unpublished client report. 
Connelly P A, Kendall T, Hunter-Mann K \& Mainman A, 2008, 'Hungate: the archaeology of modern urban poverty’, Current Archaeology No. 215 (Vol XVIII, No.11), 26-33.

Engels, F., 1845, The Conditions of the Working Class in England. London. Penguin Books edition reprinted 2005.

Gwyn D, 2006, Gwynedd. Inheriting a Revolution: The Archaeology of Industrialisation in North-West Wales. Phillimore \& Co Ltd, Chichester.

Hartwell, C., 2001, Pevsner Architectural Guides. Manchester. Penguin Books, London.

Jeffries N, Owens A, Hicks D, Featherby R \& Wehner K, 2009, 'Rematerialising metropolitan Histories? People, Places and Things in Modern London', in Horning A \& Palmer M, (eds), Crossing Paths or Sharing Tracks? Future directions in the archaeological study of post-1550 Britain and Ireland. Boydell \& Brewer Ltd, 323-50.

Kidd, A., 2002, Manchester. Edinburgh University Press. Third Edition.

Kidd A \& Wyke T, 2010, The Challenge of Cholera: Proceedings of the Manchester Special Board of Health 1831-1833. The Record Society of Lancashire and Cheshire Volume CXLV, Manchester.

Miller I, Wild C \& Gregory R, 2010, Greater Manchester's Past Revealed. Piccadilly Place. Uncovering Manchester's Industrial Origins. Oxford Archaeology.

Morton D, 2009, 'Involving the public in Glasgow's Industrial Archaeology: the M74 Dig', The Archaeologist No 74 (Winter 2009), 36-7.

Nevell, M., 2003, 'From Linen Weaver to Cotton Manufacturer: Manchester During the $17^{\text {th }}$ and $18^{\text {th }}$ centuries and the Social Archaeology of Industrialisation', in Nevell M (ed), From Farmer to Factory Owner. Models, Methodology and Industrialisation. Archaeological Approaches to the Industrial Revolution in North West England. CBA North West \& CBA North West Industrial Archaeology Panel.

Nevell, M., 2005, 'The Social Archaeology of Industrialisation: The Example of Manchester During the $17^{\text {th }}$ and $18^{\text {th }}$ Centuries', in Casella E C \& Symonds J, Industrial Archaeology. Future Directions. Springer, New York, 177-204.

Nevell M, 2008, Manchester. The Hidden History. The History Press, Stroud.

Nevell, M., \& Walker, J.S.F., 1998, A History and Archaeology of Tameside. Volume 6. Lands and Lordships in Tameside: Tameside in Transition 1348-1642. Tameside Metropolitan Borough Council with the University of Manchester Archaeological Unit.

Noble P \& Arrowsmith P, 2005, Land at the Junction of Gravel Lane \& Greengate Salford: An Archaeological Excavation. University of Manchester Archaeology Unit, unpublished client report.

Palmer M, 2004, 'The workshop: type of building or method of work?', in Barnwell P S, Palmer M \& Airs M, (eds), The vernacular workshop: from craft to industry, 1400-1900. CBA Research Report No 140. York.

Roberts, J., 1993, 'The Residential development of Ancoats', Manchester Region History Review VII, 15-26.

Symonds J, 2005, 'Dirty Old Town? Industrial archaeology and the Urban Historic Environment', in Gwyn D \& Palmer M, (eds), Understanding the Workplace. A Research Framework for Industrial Archaeology in Britain. Industrial Archaeology Review XXVII, 57-66.

Taylor S and Holder J, 2008, Manchester's Northern Quarter. The greatest meer village. English Heritage, Swindon. 
Walker L \& McNeil R, 1997, 3 \& 5 Kelvin Street (formerly Milk Street), Manchester. A Building Survey. University of Manchester Archaeology Unit, unpublished client report. 


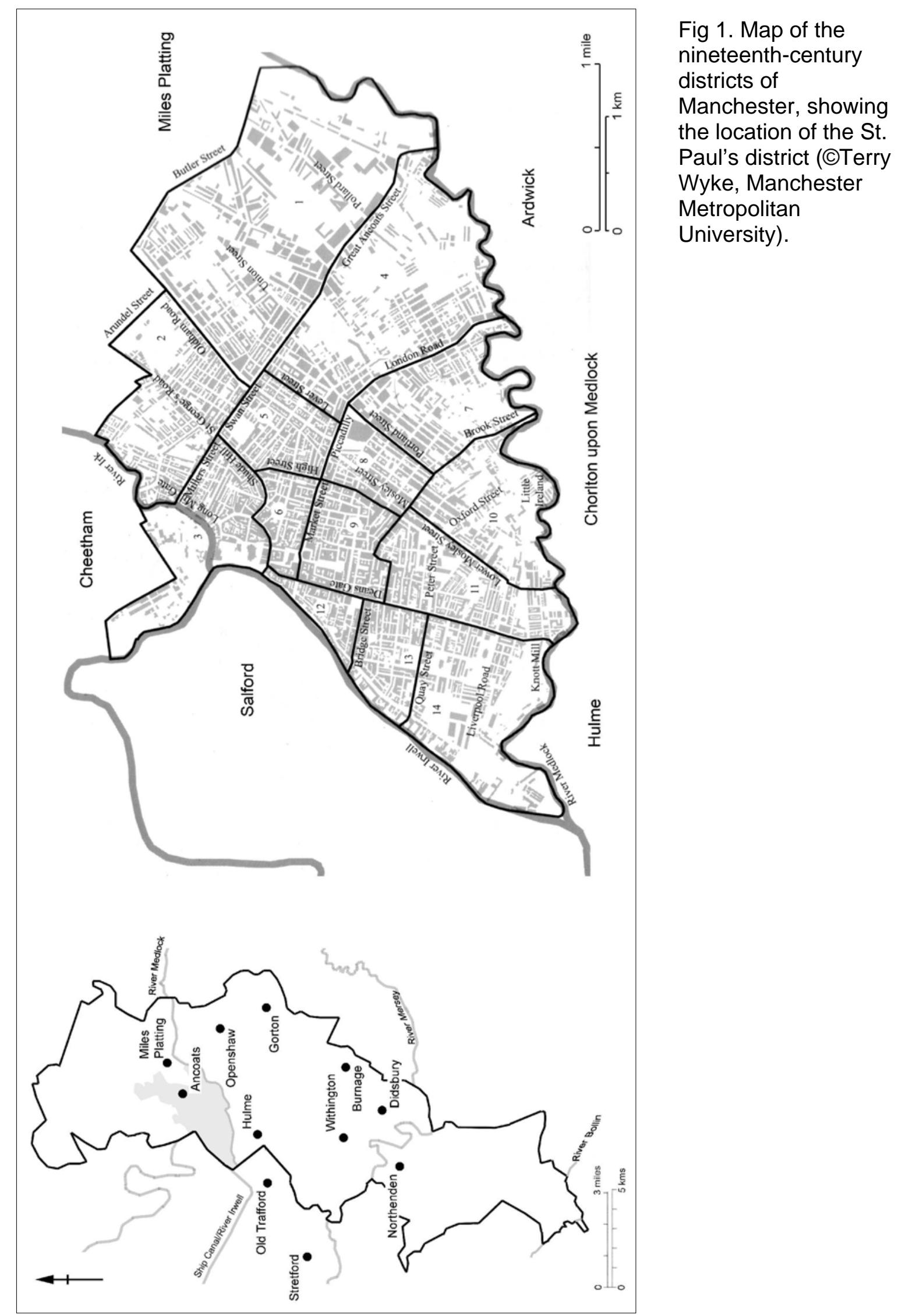




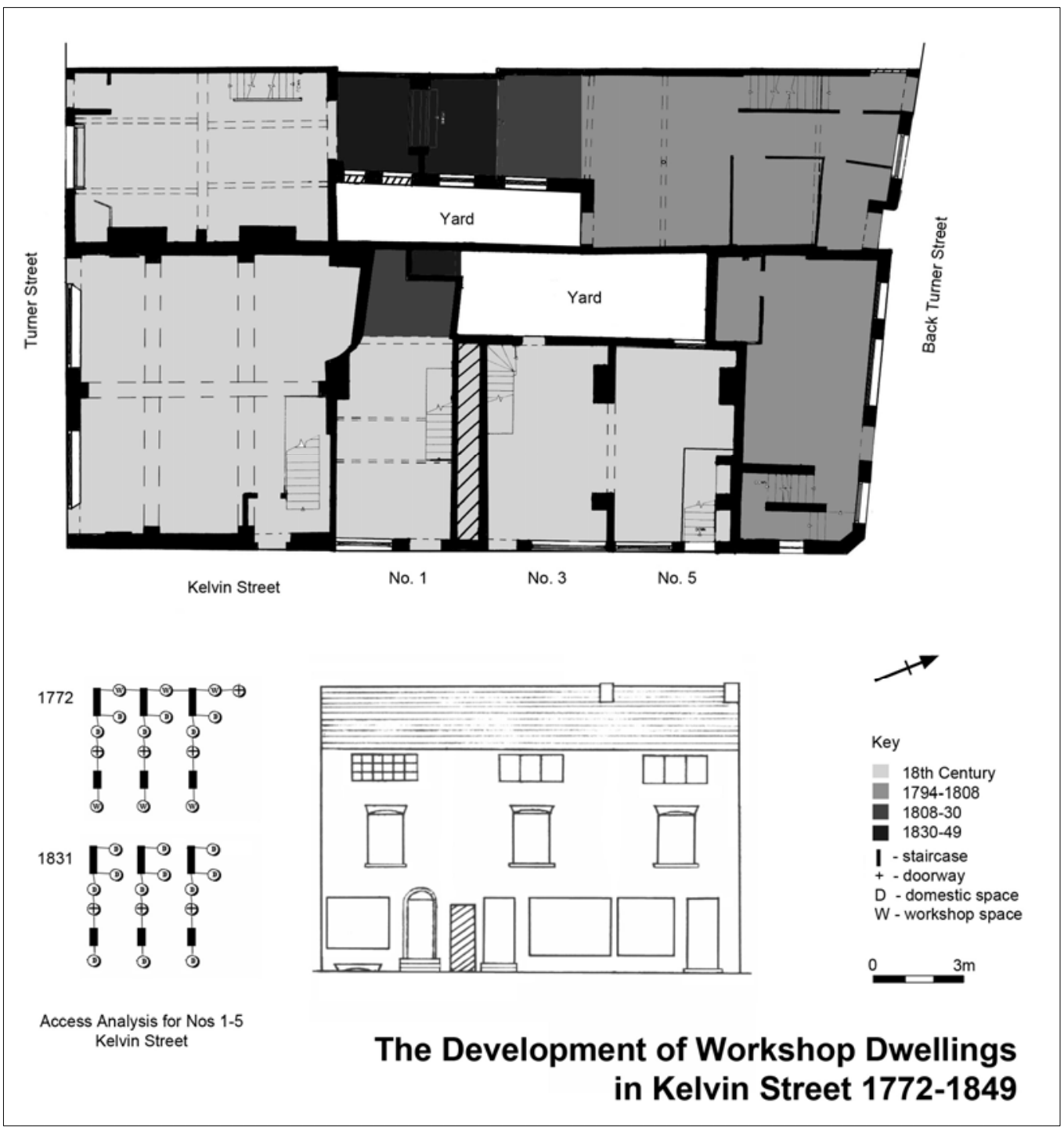

Fig 2: The Kelvin Street workshop dwellings, showing the urban development of the housing and workshops between Turner Street, Kelvin Street and Back Turner Street in the period 1794 to 1849 (CM. D. Nevell). 


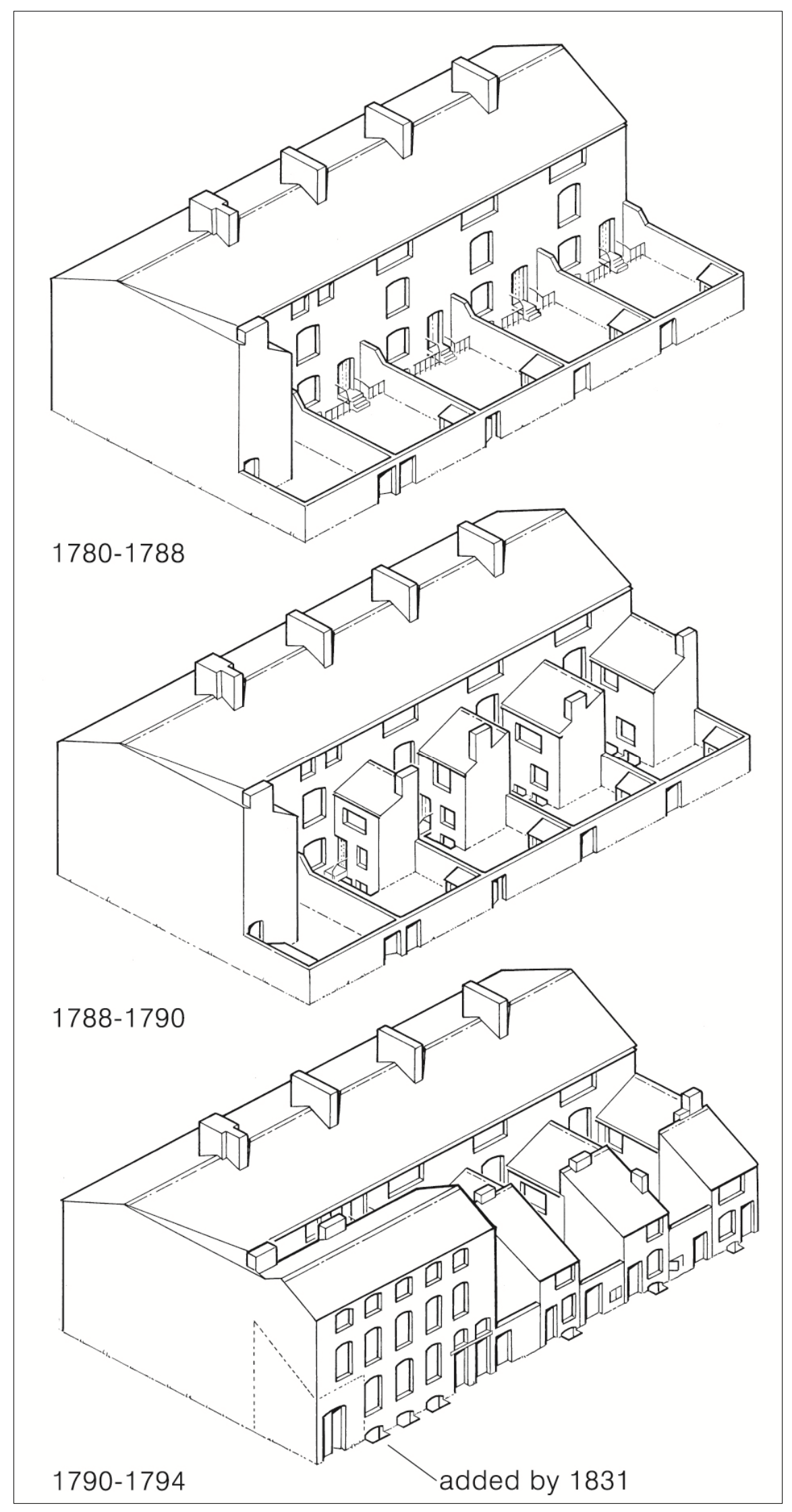

Fig 3: The

backyard

development of

nos 66-77 Lever

Street between

1788 and 1794.

(CEnglish

Heritage). 


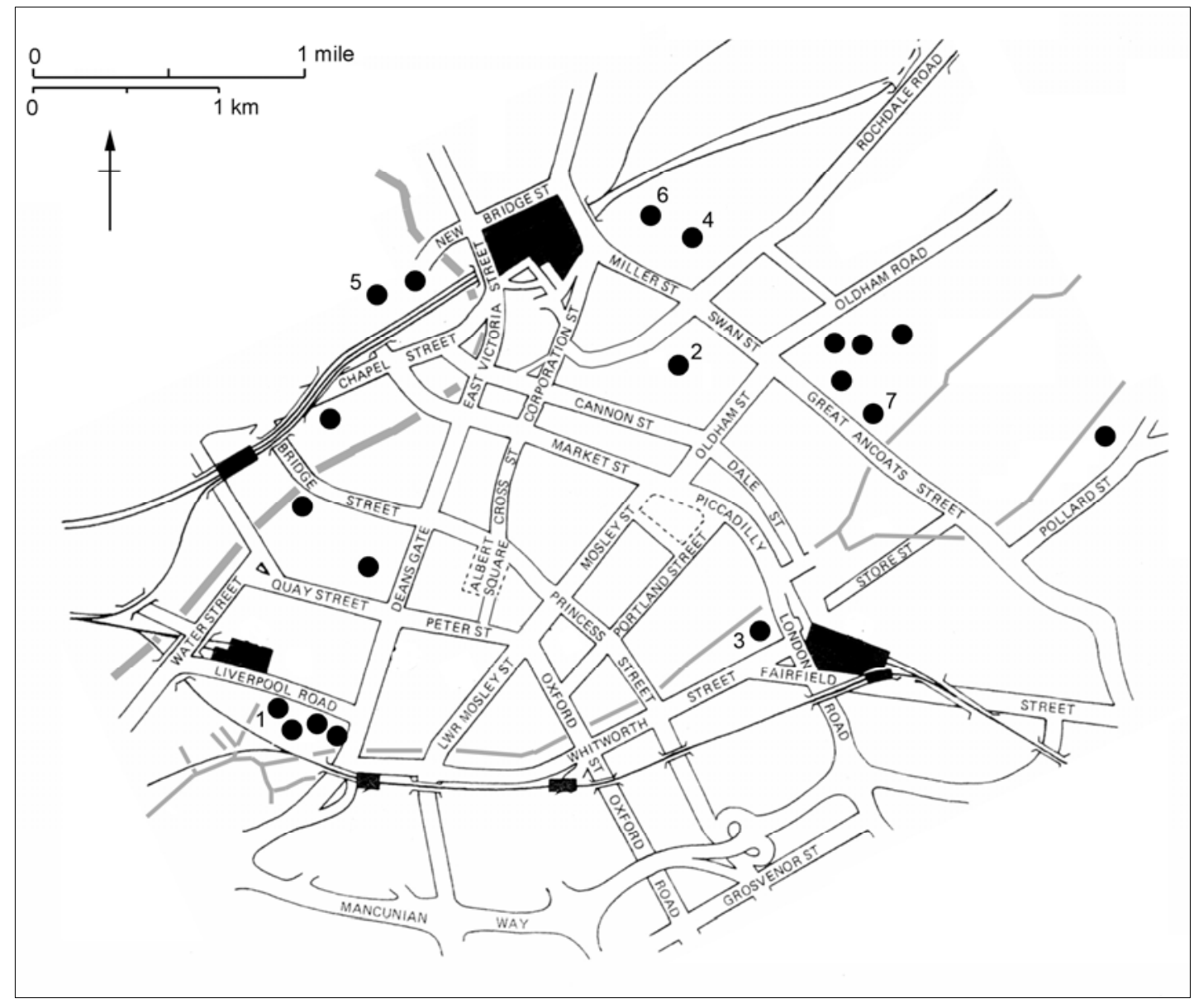

Fig 4: Workers housing excavated in Manchester and Salford between 2001 and 2011. Key to excavations: (1) Liverpool Road; (2) Copperas Street; (3) Syre's Court; (4) Angel Street; (5) Greengate; (6) Blakeley Street; (7) Pickford Street) (@M. D. Nevell). 


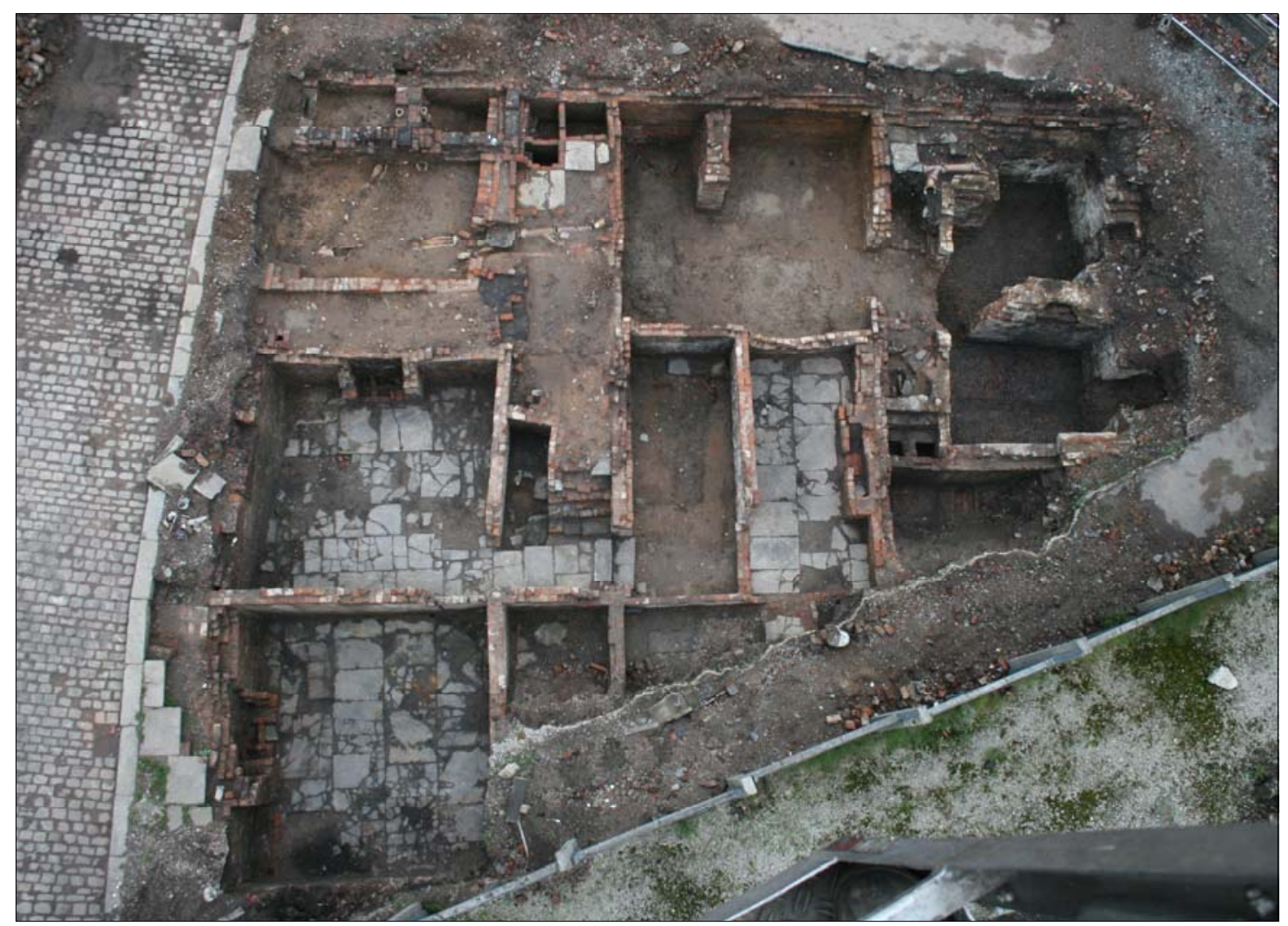

Fig 5: Late eighteenth and early nineteenth century workers housing between Angle Street and Blakeley Street showing the rear court housing. Excavated in 2009 (CIan Miller, Oxford Archaeology). 


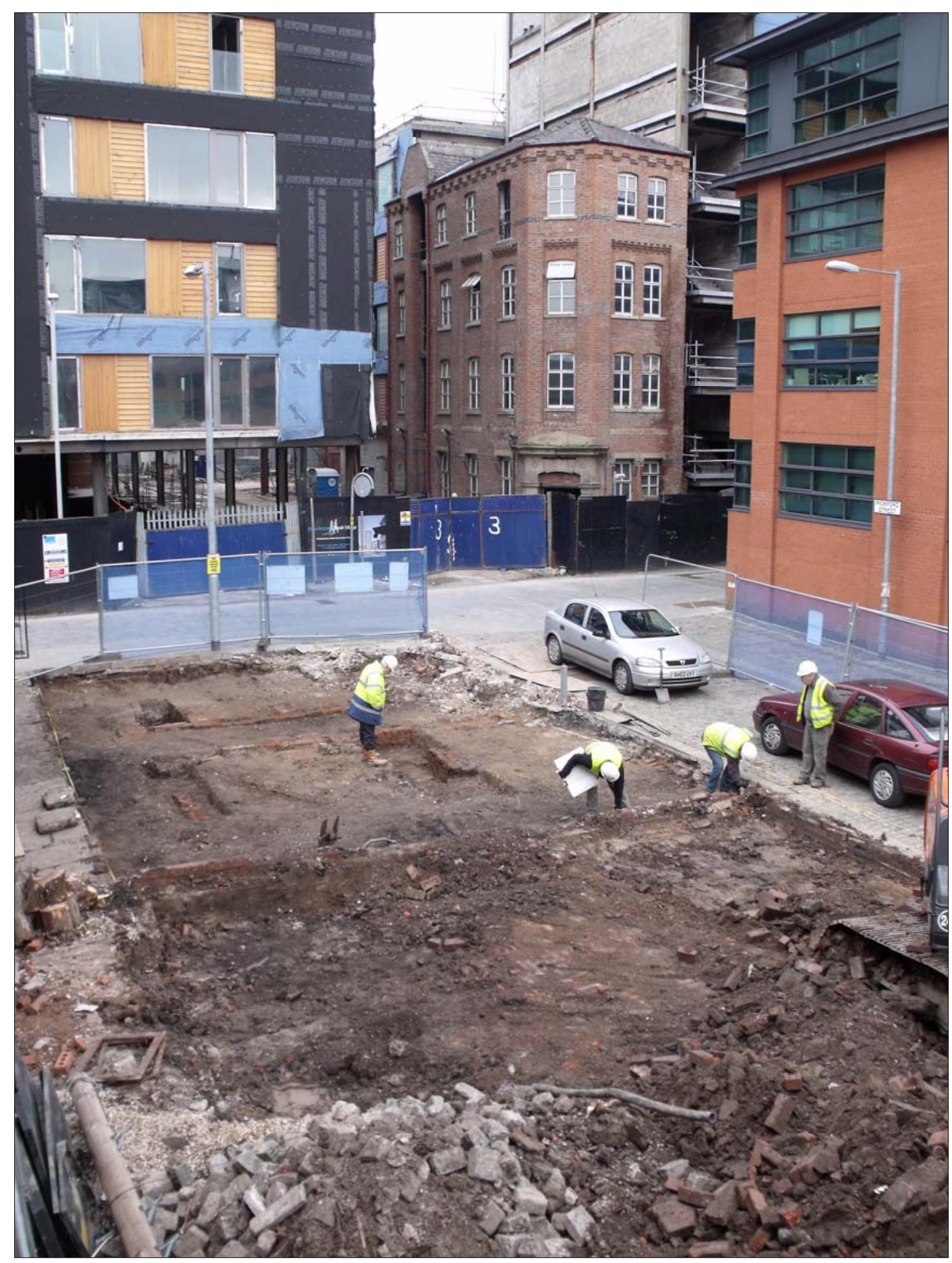

Fig 6: Excavations at Pickford Street in 2011 by the University of Salford showing a set of ten back-to-back houses with shallow foundations built on a greenfield site in the period 1794-1807 (@M. D. Nevell). 